\title{
The Antioxidant Effect of Echium Amoenum to Prevent Teratogenic Effects of Lamotrigineon the Skeletal System and Fetal Growth in Mice
}

\author{
Mahsa Kamali ${ }^{1}$ and Habibolah Johari*2 \\ ${ }^{1}$ Department of Anatomy, School of Medicine, Shiraz University of Medical Sciences, Iran \\ ${ }^{2}$ Department of physiology, Islamic Azad University, Iran
}

Submission: July 21, 2016; Published: August 02, 2017

*Corresponding author: Habibolah Johari, Department of physiology, Islamic Azad University, Darab Branch, Darab, Iran, Tel: 98-0732-6233990; Email: mhs.kamali@gmail.com

\begin{abstract}
Background and Aim: Echium amoenum is a medicinal plant with abortive properties. This study was performed to determine the effect of lamotrigine and Echium amoenum hydroalcoholic extract on the development of congenital abnormalities in BALB/c mice.

Materials and Methods: In this experimental study, 120 female mature BALB/c mice were assigned to four groups and after mating and confirming the vaginal plug, the animals in the first group (G1) were kept with no intervention, and the second (G2), third (G3) and fourth (G4) groups were intra peritoneally (IP) injected with respective lamotrigine $(25 \mathrm{mg} / \mathrm{kg}$ ), and 100 and $200 \mathrm{mg} / \mathrm{kg}$ of Echium amoenum extract with Lamotrigine (for 7 days). On the $19^{\text {th }}$ day, caesarean section was performed on the mice and embryos were examined for abnormalities. Their weight and height were measured. Data were analyzed by ANOVA.
\end{abstract}

Results: There were significant differences between G2 and G1 ( $p<0.05)$; the not significant difference was seen between G3 and G4.

Conclusion: lamotrigine have teratogenicity and should be used cautiously during pregnancy and Echium amoenum can improve it.

Keywords: Lamotrigine; Echium amoenum; Medicinal plant; Pregnancy; Teratogenicity

Abbreviations: AEDs: Antiepileptic drugs; RA: Rosmarinic Acid; GLA: Gamma-Linolenic Acid; ALA: Alpha-Linolenic Acid; IP: Intra Peritoneally

\section{Introduction}

In spite of the fact that, the majority of children born to women with epilepsy are normal, they are at increased risk for malformations [1]. Antiepileptic drugs (AEDs) have the potential to affect fetal development throughout pregnancy and unfortunately, pregnant women should not stop their medication during this time. According to the Harmful effects of synthetic drugs and increasing contraindications to their usage, there is an increasing interest in the use of medicinal plants [2,3]. Medicinal plants have also the capacities to diminish drug-induced adverse effects [4]. Most women believe that herbal medicines are safe and consequently pregnant women may use these medicinal plants or their combinations during pregnancy [5].

Echium ammonium is belonged to the Boraginaceae family and is a biennial or perennial herb indigenous to the narrow zone of the northern part of Caucasus and Iran. Echium genus (Boraginaceae) has 4 species in Iran [6] and only dried violetblue petals of Echium amoenum have medicinal uses in Iran [6]. Echium ammonium that has been shown as a rich source of antioxidants, like flavonoids and rosmarinic acid (RA). This plant grows at Highlands at the altitude ranging from 60 to $2200 \mathrm{~m}$ and it has been advocated for a variety of effects such as demulcent, and analgesic, anti-inflammatory, common cold, sedative and anxiolytic [7]. The plant constituents have been isolated by different investigators; they include gammalinolenic acid (GLA), alpha-linolenic acid (ALA), delta6-fatty acyl desaturase, delta8-sphingolipid desaturase [6] pyrrolizidine alkaloids, mucilage, resin, potassium nitrate, and calcium salt combined with mineral acids. 
Although some pharmacologic and toxic effects of lamotrigine have been investigated, however, the teratogenic effects of this drug and plant on the embryo during pregnancy have not been scientifically clarified. Therefore, in this study, the teratogenic effects of lamotrigine were studied in BALB/c mice.

\section{Materials}

Female BALB/c mice between8-12 week were purchased from the animal laboratory, Shiraz, Iran. lamotrigine was purchased from sobhandarou Pharmaceutical Company and other chemicals from Merck Company (Germany). Echium ammonium was collected in Fars (Iran).

\section{Experiments}

In this experimental study, 120 female BALB/c mice between 8-12week weighing 25-28 g were prepared and kept in proper health and light conditions (12/12 h light/darkness) without any food access limitation. After ten-day habituation to the environment, mouse, two female and one male mice were placed in a cage for two days [8]. The vaginal plug was considered as the sign of zero-day of pregnancy. As regards this method was not certain, an eosin smear 3\% was prepared from the vaginal discharges of the female mice and the being of sperm was regarded as fertility. The other sign of fertility was female mice's weight increasing after fertility. That way the mice weight increases by $3-10 \%$ daily since the fourth day of pregnancy, the weight gain up to this level or more was regarded as the sign of fertility. Then, the mice were assigned to four groups. The animals in the first group (G1) were kept with no intervention, and the second (G2), third (G3) and fourth (G4) groups were intra peritoneally (IP) injected with respective Lamotrigine (25 $\mathrm{mg} / \mathrm{kg}$ ), and 100 and $200 \mathrm{mg} / \mathrm{kg}$ of Echium amoenum extract with Lamotrigine (for 7 days) $[9,10]$.

The two doses of Echium amoenum and lamotrigine were injected daily since the zero-day of pregnancy till the seventh day. On the $19^{\text {th }}$ day of pregnancy, the caesarean operation was done under anesthesia with chloroform. The caesarean cut was in shape of inverse Y. After the caesarean section, fallopian tubes were opened and embryos were removed and after that placed in normal saline. Embryos were heights were measured by a caliper from crown to rump and their weighed by a digital sensitive were measure it. The embryos were assessed in terms of observable abnormalities. Then, after using Alizarin dye and Alcian Blue, the skeletal abnormalities were was investigated [11].

\section{Extraction Method}

The seed of Echium amoenum was collected from fars suburbs and after being authenticated by a botanist in the Research Center of Jahad-e-Keshavarzi, a herbarium sample was prepared and deposited in the Herbarium Unit of Medical Plants Research Center of Shiraz University of Medical Sciences, Iran. The collected plants were dried at a normal temperature and the extraction was done by Percolation Method. To $500 \mathrm{gm}$ of the plant powder in an appropriate container, $500 \mathrm{ml}$ of ethanol $70 \%$ was added, and after 72 hours it was filtered. The solvent was removed at $35^{\circ} \mathrm{C}$ using a rotary apparatus. The Echium amoenum extract was incubated for two days at $40^{\circ} \mathrm{C}$ to dry. Then, it was kept in refrigerator until the usage time [12].

\section{Standardization of The Extract}

To standardize, the level of phenolic compounds and flavonoids, as well as the antioxidant capacity of the extract, were measured as follows:

\section{Measurement of Flavonoid Compounds Level}

Aluminum chloride and Rutin colorimetric method was run to test the total flavonoids [13]. At First, standard solutions that include the rutin in methanol $60 \%$ at concentrations of 25,50 , 100,250 , and $500 \mathrm{ppm}$ were prepared. After that, $1 \mathrm{ml}$ of these solutions was transferred into test tubes and blended with $1 \mathrm{ml}$ of chloride aluminum 2\%. Then, $6 \mathrm{ml}$ of potassium acetate $5 \%$ was introduced and the optical density was read after 40 minutes at $415 \mathrm{~nm}$ wavelength. The concentration levels of the standard solutions were measured in three intervals. To assay the totally level of flavonoid in the extracts, $0.01-0.02 \mathrm{~g}$ of the extracts was dissolved with methanol $60 \%$, reaching $10 \mathrm{ml}$. Then, the overall level of flavonoid was measured by chloride aluminum colorimetry. However, instead of the standard solution, $1 \mathrm{ml}$ of the extract was added. The total flavonoid level was calculated in $\mathrm{mg} / \mathrm{gr}$ extract, equivalent to rutin.

\section{Measurement of Total Phenolic Compounds}

Total phenolic compounds were measured equivalent to gallic acid by Folin-Ciocalteu colorimetry [14]. The standard solutions were prepared at concentrations of $12.5,25,50,62.5$, 100 , and $125 \mathrm{ppm}$ of gallic acid in methanol $60 \%$. After that, 0.1 $\mathrm{ml}$ of each sample was transferred into a test tube and $0.5 \mathrm{ml}$ Folin-Ciocalteu $10 \%$ was introduced as a reactive agent. The solutions were left for 8 minutes at room temperature and $0.4 \mathrm{ml}$ of sodium carbonate $7.5 \%$ was added. The tubes were held for 30 minutes at the laboratory temperature and then measured in three intervals by a spectrophotometer at $765 \mathrm{~nm}$ wavelength. To measure the total phenol in the extracts, $0.01-0.02 \mathrm{~g}$ of the extracts was solved with $60 \%$ methanol, reaching $10 \mathrm{ml}$ and the total level of phenol was measured by Folin-Ciocalteu method. However, instead of the standard solution, $0.1 \mathrm{ml}$ of extract solution was added. At the end, the total phenol level was derived from the read optical density in $\mathrm{mg} / \mathrm{gr}$ extract in gallic acid equivalent.

\section{Measurement of Antioxidant Activity}

To assay, the antioxidant activity of the extract $\beta$-carotene model was used [14]. In a suitable container, $0.2 \mathrm{ml}$ Tween 40,500 $\mu \mathrm{L}$ chloroform, $5 \mathrm{ml} \beta$-carotene $(0.2 \mathrm{mg})$ and $20 \mathrm{ml}$ linoleic acid $(20 \mathrm{mg}$ ) were blended and incubated at 500C for 10 minutes to remove the solvent. The solution was diluted using distilled water 
and mixed with $4 \mathrm{ml}$ of aliquots. The control solution, consisting of $0.2 \mathrm{ml}$ ethanol and $0.2 \mathrm{ml}$ of the extracted sample with 0.05 $\mathrm{ml}$ turmeric extract $0.15 \mathrm{ml}$ ethanol, was prepared. The optical density in the Group 1(G1) was recorded at $\mathrm{t}=0$ and $\mathrm{t}=90$ at 470 $\mathrm{nm}$ wavelength, similar to the standard group. The specimens were incubated in a bain-marie at 500C. The antioxidant activity of the samples was assay based on the samples ability to prevent washing of $\beta$-carotene. The antioxidant activity of them was measured by the formula below [15]:

i. $\quad \mathrm{AA}=100[14]$ Where, Ao: optical density at $\mathrm{t}=0$, At: optical density of the sample at $t=90$, Aoo and Aot: Optical density values in the control samples at $\mathrm{t}=0$, and $\mathrm{t}=90$, respectively.

\section{Statistical Analysis}

Data were presented as frequency, relative frequency, mean, standard deviation and were analyzed using ANOVA, posthoc Turkey, using SPSS 22 software.

\section{Results}

Each $100 \mathrm{gr}$ of Echium amoenum powder yielded $8.5 \mathrm{gr}$ hydro alcoholic dried extract. The calculated levels for flavonoid and phenolic compounds were $85.37 \mathrm{mg} / \mathrm{gr}$ rutin equivalent and $117.91 \mathrm{mg} / \mathrm{gr}$ gallic acid equivalent, respectively. The extract antioxidant activity was $37.28 \%$. The indices of embryos' height and weight were measured (Table 1) and (Figures $1 \& 2$ ). There were embryos in all selected mice; however, posthoc Tukey test showed that both doses of the extract caused a not significant decrease in embryos' height and weight in comparison with the $\mathrm{G} 1(\mathrm{p}<0.05)$; however, there is a significant difference was observed in G2 compare with G1 regarding these parameters ( $\mathrm{p}>0.05)$.

Table 1: The comparison of the mice embryos' height and weight mean ( \pm standard deviation) in the groups under study.

\begin{tabular}{|c|c|c|c|c|}
\hline $\begin{array}{c}\text { Variable } \\
\text { Group }\end{array}$ & Control & lamotrigine & $\begin{array}{c}\text { Extract } \\
\mathbf{1 0 0} \mathbf{~ m g} / \mathbf{k g}\end{array}$ & $\begin{array}{c}\text { Extract 200 } \\
\mathbf{m g} / \mathbf{k g}\end{array}$ \\
\hline $\begin{array}{c}\text { Height } \\
(\mathrm{mm})\end{array}$ & $19.86 \pm 1.47$ & $17.06 \pm 0.86^{*}$ & $20.16 \pm 1.36$ & $20.10 \pm 1.39$ \\
\hline $\begin{array}{c}\text { Weight } \\
\text { (gr) }\end{array}$ & $1.72 \pm 0.63$ & $1.02 \pm 0.67^{*}$ & $1.59 \pm 0.47$ & $1.66 \pm 0.45$ \\
\hline
\end{tabular}

${ }^{*} p<0.05$ in comparison with control and lamotrigine groups.

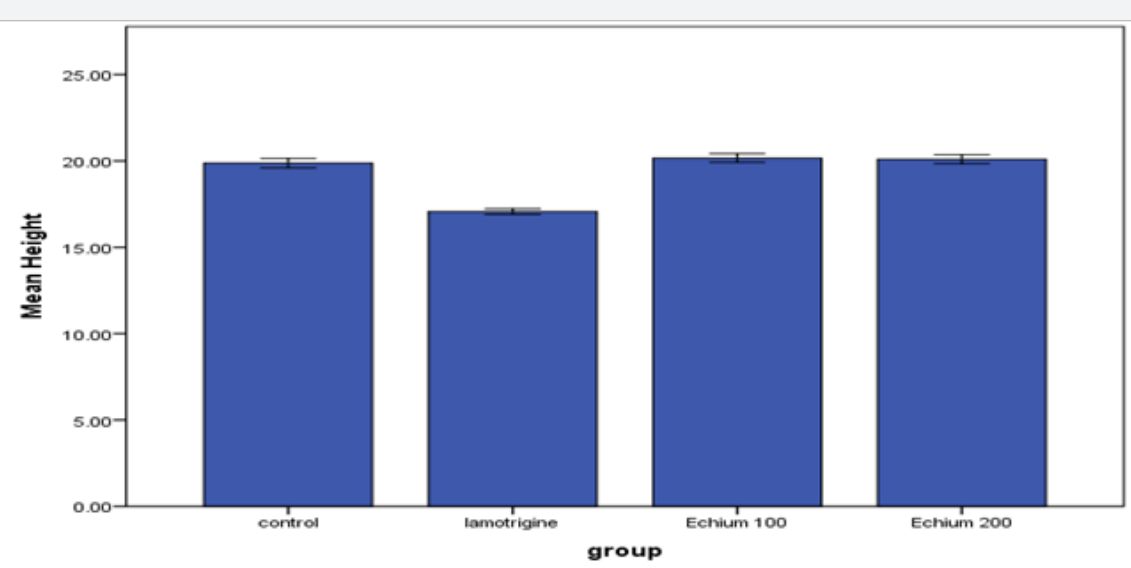

Figure 1: The comparison of the mice embryos' height mean ( \pm standard deviation) in the groups under study $(p<0.05)$.

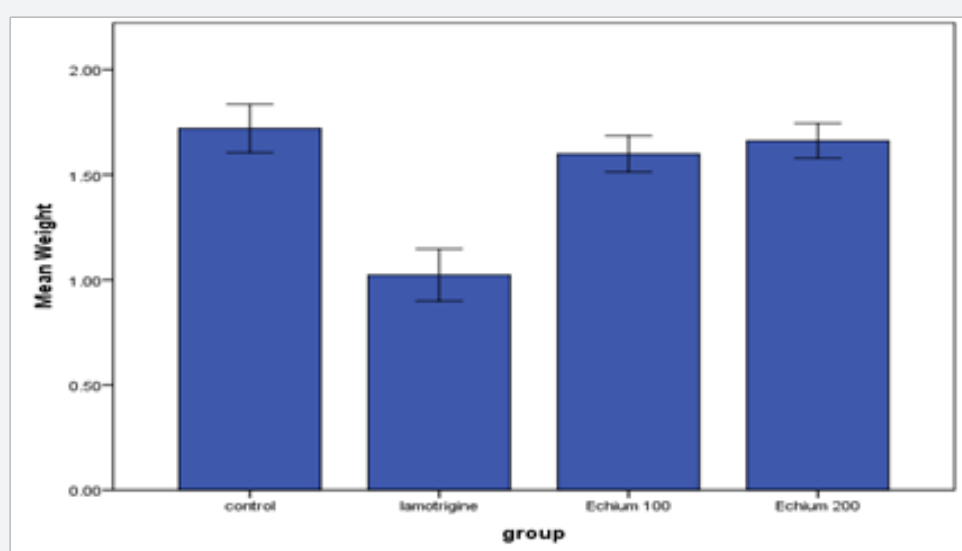

Figure 2: The comparison of the mice embryos' weight mean ( \pm standard deviation) in the groups under study $(p<0.05)$. 
Skeletal abnormalities of embryos in all groups are summarized in (Table 2) and (Figure 3). The rate of extra rib, anencephaly, exencephaly, and parietal bone abnormality of the mice embryos was zero in group $1(\mathrm{G} 1)$, but the rates of them in group2 (G2) was 5(16.7\%), 9(30\%), 7(23.3\%), and 10(33.3\%). On the other side, we examined the frequency of abnormalities in the four groups, those of G1 and G2 were compared and the difference was obtained significant $(\mathrm{p}<0.05)$.also, G4 in extra rib and Exencephaly. Based on the test, the abnormalities of the extra rib and Exencephaly were significantly higher in Group 4 compare than Gruop1 $(\mathrm{p}<0.05)$. In addition, no case of extra rib, parietal bone abnormality, Anencephaly, and Exencephaly was observed in Gruop1 and Gruop3 (Table 2) and (Figure 2). The rate of abnormalities was higher in the lamotrigine and after that in the higher dose of the extract in comparison with the lower dose was seen.

Table 2: The frequency of observed abnormalities in mice's embryos*.

\begin{tabular}{|c|c|c|c|c|c|c|c|c|}
\hline \multirow{2}{*}{ Group abnormalities } & \multicolumn{2}{|c|}{ Extra Rib } & \multicolumn{2}{c|}{ Anencephaly } & \multicolumn{2}{c|}{ Exencephaly } & \multicolumn{2}{c|}{ Parietal Bone } \\
\cline { 2 - 9 } & Frequency & Percentage & Frequency & Percentage & Frequency & Percentage & Frequency & Percentage \\
\hline Control & 0 & 0 & 0 & 0 & 0 & 0 & 0 & 0 \\
\hline lamotrigine & 5 & 16.7 & 9 & 30 & 7 & 23.3 & 10 & 33.3 \\
\hline Extract $100 \mathrm{mg} / \mathrm{kg}$ & 0 & 0 & 0 & 0 & 0 & 0 & 0 & 0 \\
\hline Extract $200 \mathrm{mg} / \mathrm{kg}$ & 1 & 3.3 & 0 & 0 & 2 & 6.7 & 0 & 0 \\
\hline
\end{tabular}

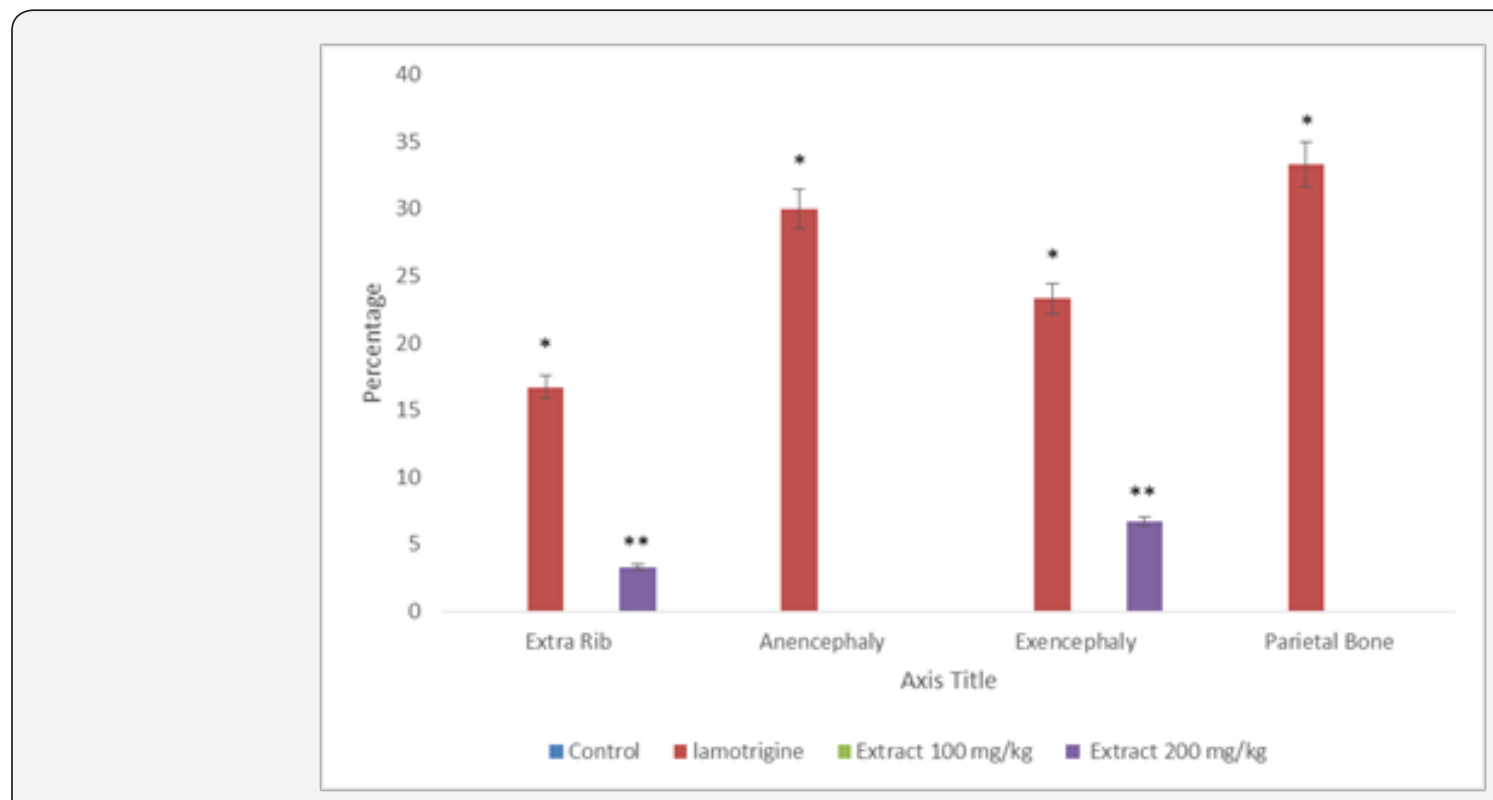

Figure 3: The comparison of the mice embryos' abnormalities in the groups under study $(p<0.05)$.

\section{Discussion}

This study tried to examine the teratogenicity of lamotrigine and antioxidant activity of Echium amoenum in BALB/c mice. In the present study, the lamotrigine drug caused skeletal abnormalities and height and weight loss in embryos. Padmanabhan et al, in 2003 reported that administering lamotrigine as a single dose of $50-200 \mathrm{mg} / \mathrm{kg}$ body weight can induce intrauterine growth retardation in mice, where as multiple doses of $25,50,75 \mathrm{mg} / \mathrm{kg}$ body weight cause a dosedependent increase in embryonic resorption and craniofacial malformations [9]. Marchi et al. [16] in 2001 report edteratogenic effects, such as reduction in body weight and morphological changes in the brain, when lamotrigine was administered to rats at 4 times the median effective dose [16]. On the other hand both doses of the extract caused a not significant decrease in embryos' height and weight in comparison with the G1 $(\mathrm{p}<0.001)$. Studies have shown that Echium amoenum contains certain amounts of fatty acids such as linoleic acid [17] and antioxidant compounds such as a rosmarinic acid [18]. And maybe it has been caused the balance weight [19].

The comparison between the group 1(G1) and group 2 (G2) showed that there was a significant difference in external and skeletal abnormalities and the lamotrigine caused anencephaly, exencephaly, extra rib abnormalities, and lack of parietal bone in mice embryos $(\mathrm{p}<0.05)$. Numerous study has argued that lamotrigine caused the teratogenic in man and have similar effects in animals, This view is supported by Prakash and et al. [20]. Previous research has shown a negative correlation 
between the lack of absorption of folic acid and skeletal abnormalities. The teratogenicity of lamotrigine in animals has also been attributed to reduced absorption of folate [2].

on the other side, in this study, abnormalities of extra rib and Exencephaly were observed in group 4 (G4); however, their incidence was higher with a dose of $200 \mathrm{mg} / \mathrm{kg}$. Therefore, it can be said that the incidence of these abnormalities depends on the dose. Apigen in is an estrogen flavonoids available in aromatic plants. It has a slow metabolism and the adsorption and desorption phases happen slowly and therefore accumulation of this flavonoid in the body is probable. Because it has been already shown that Echium amoenum, especially its hydro alcoholic extract, has high amounts of apigen in, the presence of this component in Echium amoenum hydro alcoholic extract could be one of the reasons for external and skeletal abnormalities.

\section{Conclusion}

In view of the obtained results about external and skeletal abnormalities including extra rib and Exencephaly, it seems that Echium amoenum should be taken cautiously during pregnancy. This study showed that Echium amoenum plant was able to create abnormalities in mice, and its teratogenic effects were dose-dependent and of course, the teratogenic effects of this plant should be studied more precisely.

\section{References}

1. Meador K, Baker G, Finnell R, Kalayjian L, Liporace J, et al. (2006) In utero antiepileptic drug exposure Fetal death and malformations. Neurology 67(3): 407-412.

2. Bahmani M, Rafieian-Kopaei M, Hassanzadazar H, Saki K, Karamati SA (2014) A review on most important herbal and synthetic antihelmintic drugs. Asian Pacific journal of tropical medicine 7: S29-S33.

3. Delfan B, Bahmani M, Hassanzadazar H, Saki K, Rafieian-Kopaei M (2014) Identification of medicinal plants affecting on headaches and migraines in Lorestan Province, West of Iran. Asian Pacific journal of tropical medicine 7S1: S376-S379.

4. Asadi-Samani M, Bahmani M, Rafieian-Kopaei M (2014) The chemical composition, botanical characteristic and biological activities of Borago officinalis: a review. Asian Pacific journal of tropical medicine 7: S22-S28.

5. Shirzad H, Nasri H (2014) Toxicity and safety of medicinal plants. Journal of HerbMed Pharmacology. 2(2).

6. Mehrabani M, Shams-Ardakani M, Ghannadi A, Ghassemi-Dehkordi N, Sajjadi-Jazi S (2010) Production of rosmarinic acid in Echium amoenum
Fisch. and CA Mey. cell cultures. Iranian Journal of Pharmaceutical Research 2005: 111-115.

7. Kast RE (2001) Borage oil reduction of rheumatoid arthritis activity may be mediated by increased cAMP that suppresses tumor necrosis factor-alpha. International immunopharmacology 1(12): 2197-2199.

8. Rabiei Z, Rafieian-kopaei M, Heidarian E, Saghaei E, Mokhtari S (2014) Effects of Zizyphus jujube extract on memory and learning impairment induced by bilateral electric lesions of the nucleus Basalis of Meynert in rat. Neurochemical research 39(2): 353-360.

9. Padmanabhan R, Abdulrazzaq Y, Bastaki S, Shafiullah M, Chandranath S (2003) Experimental studies on reproductive toxicologic effects of lamotrigine in mice. Birth Defects Research Part B: Developmental and Reproductive Toxicology 68(5): 428-438.

10. Chen Y, He X, Sun Q Fang Z, Zhou L (2017) Effect of lamotrigine on seizure development in a rat pentylenetetrazole kindling model. Brain and Behavior 7(7): e00727.

11. Jafarzadeh L, Rafieian-Kopaei M, Samani RA, Asgari A (2012) The effect of hydroalcoholic extract of Stachys lavandulifolia vahl on pregnant mice. EXCLI journal 11: 357.

12. Duke JA (2008) Duke's handbook of medicinal plants of Latin America: CRC Press, USA.

13. Rafieian-Kopaei M, Baradaran A, Merrikhi A, Nematbakhsh M, Madihi Y, et al. (2013) Efficacy of Co-Administration of Garlic Extract and Metformin for Prevention of Gentamycine-Renal Toxicity in Wistar Rats: A Biochemical Study. International journal of preventive medicine 4(3): 258-264.

14. Chaleshtori Rs, Chaleshtori Fs, Rafieian M (2011) Biological characterization of Iranian walnut (Juglans regia) leaves. Turkish Journal of Biology 25(5): 635-639.

15. Asadi SY, Parsaei P, Karimi M, Ezzati S, Zamiri A, et al. (2013) Effect of green tea (Camellia sinensis) extract on healing process of surgical wounds in rat. International Journal of Surgery 11(4): 332-337.

16. Marchi NSAd, Azoubel R, Tognola WA (2001) Teratogenic effects of lamotrigine on rat fetal brain: a morphometric study. Arquivos de neuro-psiquiatria 59(2B): 362-364.

17. Abolhassani M (2010) Antiviral activity of borage (Echium amoenum). Archives of medical science: AMS 6(3): 366-369.

18. Mehrabani M, Ghannadi A, Sajjadi E, Ghassemi N, Shams-Ardakani (2006) M Toxic Pyrrolizidine Alkaloids of Echium Amoenum Fisch. \& Mey. DARU Journal of Pharmaceutical Sciences 14(3): 122-127.

19. Sadeghzadeh F, Eidi A, Parivar K, Mazooji A (2008) Hypoglycemic Effect of Alcoholic Extract of Salvia nemorosa in Normal and Diabetic Male Rats 32(3): 233-138.

20. Prakash PL, Nasar M, Rai R, Madhyastha S, Singh G (2007) Lamotrigine in pregnancy: safety profile and the risk of malformations. Singapore Med J 48(10): 880-883. 


\section{Your next submission with Juniper Publishers will reach you the below assets}

- Quality Editorial service

- Swift Peer Review

- Reprints availability

- E-prints Service

- Manuscript Podcast for convenient understanding

- Global attainment for your research

- Manuscript accessibility in different formats (Pdf, E-pub, Full Text, Audio)

- Unceasing customer service

Track the below URL for one-step submission https://juniperpublishers.com/online-submission.php 